Volume. 3 Nomor. 2

Periode: Juli - Desember 2019; hal. 74-80

p-ISSN : 2580-1112; e-ISSN : 2655-6669

Copyrighr@2019

Jurnal Ilmiah Keperawatan Orthopedi

Penulis memiliki hak cipta atas artikel ini

(JIKO)

journal homepage: https://ejournal.akperfatmawati.ac.id

\title{
Penerapan Terapi Rendam Kaki Menggunakan Air Hangat Dalam Menurunkan Tekanan Darah
}

\author{
Siti Utami Dewi ${ }^{1}$, Putri Ayu Rahmawati ${ }^{2}$ \\ Akademi Keperawatan Fatmawati, Jakarta
}

\begin{abstract}
Abstrak
Menurut World Health Organization (WHO) dikawasan Asia Tenggara populasi penderita hipertensi sebesar $8 \%$ atau 147 juta jiwa dan diperkirakan pada tahun 2050 meningkat 3 kali lipat dari tahun 2013. Hasil Riset Kesehatan Dasar (Riskesdas) tahun 2018 yang terdiagnosa hipertensi oleh dokter 8,36\% dan $34,11 \%$ berdasarkan hasil pengukuran. Hipertensi merupakan silent killer atau pembunuh diam-diam karena merupakan penyakit yang tidak menampakkan gejala yang khas, dimana salah satunya adalah sakit kepala dan mudah lelah. Studi kasus ini bertujuan untuk mengetahui gambaran terapi rendam kaki menggunakan air hangat dalam menurunkan tekanan darah pada subjek dengan hipertensi. Rancangan studi kasus ini menggunakan metode deskriptif dengan pendekatan proses asuhan keperawatan keluarga. Hasil dari studi kasus ini setelah tiga hari subjek menerapkan terapi rendam kaki didapatkan hasil terjadi penurunan tekanan darah pada kedua subjek, yang ditunjukan pada subjek I tekanan darah sebelum terapi $160 / 100 \mathrm{mmHg}$ menjadi $120 / 80 \mathrm{mmHg}$. Pada subjek II sebelum terapi 150/100 $\mathrm{mmHg}$ menjadi $130 / 80 \mathrm{mmHg}$, rata-rata selisih dalam penurunan tekanan darah sebelum dan sesudah terapi rendam kaki yaitu $10 \mathrm{mmHg}$. Kesimpulan studi kasus ini terapi rendam kaki cukup efektif dalam menurunkan tekanan darah pada penyakit hipertensi. Saran yang dianjurkan keluarga dan subjek dapat melakukan penerapan terapi rendam kaki, perawatan hipertensi dan kontrol ke fasilitas kesehatan.
\end{abstract}

Kata Kunci: Hipertensi, Tekanan Darah, Terapi Rendam Kaki.

\begin{abstract}
According to World Health Organization (WHO), population of hypertension patients in the Southeast Asian region is $8 \%$ or 147 million people and estimated in 2050 will increase 3-fold from 2013. The result of Riset Kesehatan Dasar in 2018, diagnosed with hypertension by doctor $8,36 \%$ and $34,11 \%$ based on measurement result. Hypertension is a silent killer, because it does not show typical symptoms. One of the symptoms are headache and fatigue. The purpose of this study is to find out correlation of foot soak therapy by using warm water to decrease blood pressure on subjects with hypertensive. This case study design is used descriptive method with a family nursing care process approach. The results of this case study during three days is decrease blood pressure on both subjects, it can be seen on subject I before the therapy was 160/100 $\mathrm{mmHg}$ and after therapy was 120/80 $\mathrm{mmHg}$. At the same time on subject II, blood
\end{abstract}

\footnotetext{
1 e-mail: utamidewi1701@gmail.com

2e-mail: putriayu980105@gmail.com
} 
pressure before therapy is $150 / 100 \mathrm{mmHg}$ and after that is $130 / 80 \mathrm{mmHg}$, average difference in decrease blood pressure before and after the foot soak therapy is $10 \mathrm{mmHg}$. The conclusion in this case study, the foot soak therapy effective to decrease blood pressure on patients with hypertension. The suggestion is the foot soak therapy can be used to decrease blood pressure on families and subjects with hypertensive, also hypertension treatment, and control to health facilities.

Key Words: Blood Pressure, Hypertension, Therapy of Foot Soak.

\section{Pendahuluan}

Hipertensi didefinisikan sebagai tekanan darah sistolik lebih dari 140 mmHg dan tekanan dia stolik lebih dari $90 \mathrm{mmHg}$, berdasarkan pada dua kali pengukuran atau lebih (Brunner, 2013). Hipertensi merupakan silent killer atau pembunuh diam-diam karena merupakan penyakit yang tidak menampakkan gejala yang khas. Gejalanya adalah sakit kepala, sesak napas, jantung berdebar-debar, mudah lelah, telinga berdenging (tinitus), mimisan, penglihatan kabur yang disebabkan oleh kerusakan pada otak, mata, jantung dan ginjal Tilong (2015 dalam Sari, 2015).

Menurut American Heart Association (AHA) penduduk di Amerika yang berusia diatas 20 tahun penderita hipertensi mencapai 74,5 juta jiwa. Menurut World Health Organization (WHO) di kawasan Asia Tenggara populasi penderita hipertensi sebesar $8 \%$ atau 147 juta jiwa dan diperkirakan pada tahun 2050 meningkat 3 kali lipat dari tahun 2013. Sedangkan di Indonesia sendiri pada tahun 2020 diperkirakan jumlah penderita hipertensi mencapai sekitar 80 juta jiwa.

Hasil Riset Kesehatan Dasar (Riskesdas) tahun 2007 prevalensi hipertensi terjadi penurunan $31,7 \%$ menjadi $25,8 \%$ pada tahun 2013 sedangkan pada 2018 yang terdiagnosa oleh dokter $8,36 \%$ dan $34,11 \%$ berdasarkan hasil pengukuran. Dan prevalensi hipertensi di DKI Jakarta pada tahun 2007 sebanyak 28,8\%, pada tahun 2013 sebanyak $20 \%$ dan tahun 2018 mengalami penurunan $10,1 \%$.
Berdasarkan data laporan tahunan Puskesmas Kecamatan Pancoran Jakarta Selatan pada tahun 2017 didapatkan 5.768 orang yang menderita hipertensi dan kasus lama 7.416 orang, sedangkan pada tahun 2018 penderita hipertensi sebanyak 1.088 orang dengan jumlah penduduk keseluruhan 129.266 orang, dengan hasil 8,4\%.

Penyakit hipertensi termasuk penyakit tidak menular, sehingga Kemenkes membuat kebijakan yaitu: mengembangkan dan memperkuat kegiatan deteksi dini hipertensi secara aktif (skrining), Meningkatkan akses masyarakat terhadap pelayanan deteksi dini melalui kegiatan Posbindu Penyakit Tidak Menular (PTM) dan meningkatkan akses penderita terhadap pengobatan hipertensi melalui revitalisasi Puskesmas untuk pengendalian PTM melalui peningkatan sumber daya tenaga kesehatan yang profesional dan kompenten dalam upaya pengendalian PTM khususnya tatalaksana PTM di fasilitas pelayanan kesehatan dasar seperti Puskesmas.

Peningkatan manajemen pelayanan pengendalian PTM secara komprehensif (terutama promotif dan preventif) dan holistik, serta peningkatkan ketersediaan sarana dan prasarana promotif preventif, maupun sarana prasarana diagnostik dan pengobatan (Depkes, 2012).

Keluarga merupakan unit pelayanan kesehatan yang terdepan dalam meningkatkan derajat kesehatan komunitas. Keluarga sebagai sistem yang berinteraksi dan merupakan unit utama yang menyangkut kehidupan masyarakat. 
Keluarga menempati posisi antara individu dan masyarakat. Apabila setiap keluarga sehat, akan tercipta komunitas yang sehat.

Masalah yang dialami anggota keluarga dapat mempengaruhi anggota keluarga yang lain, karena keluarga merupakan perantara yang efektif dan mudah untuk berbagai usaha usaha kesehatan masyarakat. Sehingga dengan memberikan pelayanan kesehatan kepada keluarga, perawat mendapat dua keuntungan yaitu dapat memenuhi kebutuhan individu dan memenuhi kebutuhan masyarakat. Jadi untuk membangun keluarga yang sehat dibutuhkan peran perawat dalam memberikan asuhan keperawatan keluarga (Damayanti, 2014).

Asuhan keperawatan keluarga adalah suatu rangkaian kegiatan yang diberikan melalui praktik keperawatan dengan sasaran keluarga, pada tatanan komunitas yang bertujuan untuk menyelesaikan masalah kesehatan yang dialami keluarga dengan menggunakan pendekatan proses keperawatan, berlandaskan pada etika dan etiket keperawatan, dalam lingkup wewenang serta tanggung jawab keperawatan (Lobo, 2015).

Penatalaksanaan hipertensi terbagi menjadi dua yaitu, terapi secara farmakologi dan non farmakologi. Pengobatan farmakologi banyak menyembuhkan hipertensi namun banyak memiliki efek samping seperti sakit kepala, pusing lemas dan mual terutama pada lansia yang sudah mengalami penurunan, sedangkan pengobatan hipertensi secara non-farmakologi dapat dilakukan dengan mengubah gaya hidup menjadi lebih sehat, seperti berhenti merokok, menurunkan konsumsi alkohol berlebih, menurunkan asupan garam dan lemak, meningkatkan konsumsi buah dan sayur, penurunan berat badan berlebih, latihan fisik dan terapi alternatif komplementer "Hidrotherapy" (Ferayati, 2017).
Hidrotherapy dapat menurunkan tekanan darah jika dilakukan secara rutin metode yang umum digunakan dalam hidroterapi salah satunya yaitu merendam kaki menggunakan air hangat. Secara ilmiah air hangat mempunyai dampak fisiologis bagi tubuh. Pertama berdampak pada pembuluh darah dimana hangatnya air membuat sirkulasi darah menjadi lancar, yang kedua adalah factor pembebanan di dalam air yang akan menguatkan otot-otot dan ligamen yang mempengaruhi sendi tubuh (Lalage, 2015).

Air hangat mempunyai dampak fisiologi bagi tubuh sehingga rendam kaki air hangat dapat digunakan sebagai salah satu terapi yang dapat memulihkan otot sendi yang kaku serta menyembuhkan stroke apabila dilakukan melalui kesadaran dan kedisiplinan. Hidrotherapy rendam hangat ini sangat mudah dilakukan oleh semua orang, tidak membutuhkan biaya yang mahal, dan tidak memiliki efek samping yang berbahaya.

Prinsip kerja dari hidroterapi rendam air hangat ini yaitu dengan menggunakan air hangat yang bersuhu sekitar $31^{\circ} \mathrm{C}$ sampai $37^{\circ} \mathrm{C}$ diatas suhu tubuh sehingga pasien nyaman (Ningtiyas, 2014). secara konduksi dimana terjadi perpindahan panas dari air hangat ke tubuh sehingga akan membantu meningkatkan sirkulasi darah dengan memperlebar pembuluh darah akibatnya lebih banyak oksigen dipasok ke jaringan yang mengalami pembengkakan dan ketegangan otot.

Perbaikan sirkulasi darah juga memperlancar sirkulasi getah bening sehingga membersihkan tubuh dari racun. Oleh karena itu orang-orang yang menderita penyakit seperti rematik, radang sendi, linu panggul, sakit punggung, insomnia, kelelahan, stres, sirkulasi darah yang buruk (hipertensi), nyeri otot, kram, kaku, terapi air bisa digunakan untuk meringankan masalah tersebut (Restuningtyas, 2019). 
Dilihat dari hasil penelitian Istiqomah (2017), sumber data primer membagi klasifikasi sistol dan diastol setelah merendam kaki menggunakan air hangat menjadi 3 klasifikasi yaitu, normal dengan sistol 5,3\% dan diastol $21,1 \%$, sedang sistol $78,9 \%$ dan diastol $47,4 \%$, dan tinggi sistol $15,8 \%$ dan diastol 31,6\%.

Dan hasil penelitian menunjukan sebelum dilakukan rendam kaki menggunakan air hangat tekanan darah sistol dan diastol rata-rata $78,9 \%$ klasifikasi sedang. Sedangkan hasil sesudah dilakukan rendam kaki menggunakan air hangat tekanan darah sistolik dan diastolik rata-rata $52,3 \%$ klasifikasi normal.

Tabel 1. Klasifikasi Hipertensi

\begin{tabular}{ccc}
\hline Kategori & $\begin{array}{c}\text { Sistol } \\
(\mathrm{mmHg})\end{array}$ & $\begin{array}{c}\text { Diastol } \\
(\mathrm{mmHg})\end{array}$ \\
\hline Normal & $<130$ & $<85$ \\
\hline Ringan & $140-159$ & $90-99$ \\
\hline Sedang & $160-179$ & $100-109$ \\
\hline Berat & $\geq 180$ & $\geq 110$ \\
\hline
\end{tabular}

Sumber : WHO, (2007)

Melihat manfaat dari terapi rendam air hangat ini, penulis terpacu untuk melakukan studi kasus mengenai penerapan rendam kaki menggunakan air hangat terhadap penurunan tekanan darah pada klien dengan hipertensi.

\section{Metode}

Studi kasus ini menggunakan metode deskriptif dan bertujuan untuk mengeksplorasi asuhan keperawatan pada keluarga dengan fokus intervensi rendam kaki menggunakan air hangat di wilayah kerja Puskesmas Kecamatan Pancoran Jakarta Selatan. Pendekatan yang digunakan adalah pendekatan asuhan keperawatan keluarga yang meliputi pengkajian keperawatan, diagnosa keperawatan, perencanaan keperawatan, pelaksanaan keperawatan dan evaluasi keperawatan.
Pada studi kasus ini memiliki kriteria inklusi yaitu, bersedia menjadi responden, telah terdiagnosa hipertensi serta didukung oleh etiologi dan hasil pemeriksaan penunjang yang jelas, belum mendapatkan pelaksanaan rendam kaki menggunakan air hangat atau telah mendapatkan pelaksanaan rendam kaki menggunakan air hangat, berada di dalam area kerja Puskesmas Kecamatan Pancoran Jakarta Selatan, dapat dilakukan observasi yang menghasilkan data akurat dalam pelaksanaan tindakan keperawatan khususnya observasi rendam kaki menggunakan air hangat pada klien hipertensi, Keluarga kooperatif dan bisa diajak bekerja sama saat dilakukan pelaksanaan untuk menjadi subjek dalam pelaksanaan studi kasus.

Kriteria eksklusi yang tidak bisa dijadikan sebagai responden yaitu: belum atau tidak terdiagnosa hipertensi, di luar area kerja Puskesmas Kecamatan Pancoran Jakarta Selatan, mengalami penurunan kesadaran atau gangguan tertentu yang menimbulkan hambatan dalam komunikasi antara perawat dan klien, tidak bersedia untuk menjadi subjek dalam studi kasus, keluarga tidak dapat di ajak kerja sama.

Instrumen yang digunakan untuk mendapatkan hasil dari variabel independen dengan menggunakan sphygmomanometer dan stetoskop, sedangkan variabel dependen menggunakan thermometer air, baskom, handuk, dan wadah air atau termos air hangat. Teknik pengumpulan data yang digunakan adalah lembar observasi.

\section{Hasil dan Pembahasan}

Dari hasil studi kasus penerapan terapi rendam kaki menggunakan air hangat yang telah dilakukan pada kedua subjek hipertensi diperoleh hasil adanya penurunan tekanan darah, sebelum dan sesudah dilakukan terapi rendam kaki selama 3 hari. Pada Tn. A hasil tekanan darah sebelum dilakukan terapi rendam 
kaki 160/100 mmHg menjadi 120/80 mmHg, sedangkan Ny. M hasil tekanan darah sebelum dilakukan terapi rendam kaki 150/100 mmHg menjadi 130/80 $\mathrm{mmHg}$.

Tabel 2. Hasil Pemeriksaan Tekanan Darah

\begin{tabular}{cccc}
\hline Subjek & Tanggal & $\begin{array}{c}\text { Tekanan } \\
\text { Darah }\end{array}$ & Klasifikasi \\
\hline Tn. A & $04 / 03 / 19$ & $160 / 100$ & $\begin{array}{c}\text { Klasifikasi } \\
\text { sedang }\end{array}$ \\
\hline Ny. M & $04 / 03 / 19$ & $150 / 100$ & $\begin{array}{c}\text { Klasifikasi } \\
\text { ringan }\end{array}$ \\
\hline
\end{tabular}

Hasil studi kasus ini sesuai dengan teori Tilong (2013), yang menyatakan bahwa merendam kaki dalam air panas adalah prosedur yang sederhana namun efektif efeknya terhadap sirkulasi darah dalam tubuh. Dengan membesarkan pembuluh-pembuluh darah pada kaki dan tungkai, maka merendam kaki dalam air panas itu dapat melancarkan aliran darah dan meredakan sumbatan-sumbatan di bagian tubuh yang lain.

Karakteristik subjek yang menderita penyakit hipertensi yaitu berusia lansia awal dimana Tn. A berusia 60 tahun dan Ny. M berusia 59 tahun. Hal ini sesuai dengan Triyanto (2014), yaitu usia karena dengan bertambahnya usia akan mengakibatkan risiko terkena hipertensi, usia yang semakin bertambah akan mengakibatkan dinding arteri pada usia lanjut mengalami penebalan yang mengakibatkan penumpukan zat kolagen yang menyebabkan penyempitan pembuluh darah dan meningkatkan kerja jantung.

Pada faktor jenis kelamin kedua subjek berbeda jenis kelamin, Tn. A berjenis kelamin laki-laki didapatkan hasil tekanan darah setelah 3 hari melakukan terapi rendam kaki mengalami penurunan secara bertahap yaitu, $160 / 100 \mathrm{mmHg}$ menjadi $120 / 80$ mmHg. Sedangkan Ny. M berjenis kelamin perempuan didapatkan hasil tekanan darah setelah 3 hari melakukan terapi rendam kaki mengalami penurunan secara bertahap yaitu dari 150/100 $\mathrm{mmHg}$, menjadi 130/80 mmHg.

Hal ini sesuai dengan teori yaitu, setelah pubertas, laki-laki cenderung memiliki tekanan darah yang lebih tinggi dan wanita setelah menepouse cenderung memiliki tekanan darah yang lebih tinggi. Hal ini berada pada teori yang mengatakan hipertensi lebih tinggi lakilaki dari pada wanita sampai usia 55 tahun (Perry \& Potter, 2010).

Hasil tekanan darah Tn. A pada hari ketiga menjadi klasifikasi normal yaitu $120 / 80 \mathrm{mmHg}$, selain minum obat dan terapi rendam kaki Tn. A mengatakan rutin olahraga setiap pagi hari, namun masih suka makan-makanan yang asin. Sedangkan tekanan darah Ny. $M$ pada hari ketiga masih pada klasifikasi ringan yaitu 130/80 $\mathrm{mmHg}$, namun $\mathrm{Ny}$. $\mathrm{M}$ masih suka makan-makanan yang asin dan jarang olahraga.

Sehingga gaya hidup merupakan faktor penting yang mempengaruhi kehidupan masyarakat. Gaya hidup yang tidak sehat dapat menjadi penyebab terjadinya hipertensi misalnya aktivitas fisik dan stres (Mahmudah, 2015). Sedangkan menurut jurnal Mahmudah (2015), pola makan yang salah merupakan salah satu faktor risiko yang meningkatkan penyakit hipertensi. Faktor makanan modern sebagai penyumbang utama terjadinya hipertensi.

Tabel 3. Observasi Tekanan Darah

\begin{tabular}{|c|c|c|c|c|c|}
\hline \multirow{3}{*}{$\begin{array}{c}\text { Hari// } \\
\text { Tanggal }\end{array}$} & \multicolumn{4}{|c|}{ Hasil pengukuran tekanan darah } & \multirow{3}{*}{$\begin{array}{c}\text { Selisih } \\
\text { Hasil }\end{array}$} \\
\hline & \multicolumn{2}{|c|}{ Tn. A } & \multicolumn{2}{|c|}{ Ny. M } & \\
\hline & Sebelum & Sesudah & Sebelum & Sesudah & \\
\hline $\begin{array}{c}\text { Rabu, } 6 \\
\text { Maret } \\
2019\end{array}$ & $160 / 100$ & $140 / 90$ & - & - & $\begin{array}{c}20 \\
\mathrm{mmHg}\end{array}$ \\
\hline $\begin{array}{c}\text { Kamis, } \\
7 \text { Maret } \\
2019 \\
\end{array}$ & $130 / 90$ & $130 / 80$ & - & - & $\begin{array}{c}10 \\
\mathrm{mmHg}\end{array}$ \\
\hline $\begin{array}{l}\text { Jum'at, } \\
8 \text { Maret } \\
2019\end{array}$ & $130 / 80$ & $120 / 80$ & $150 / 100$ & $130 / 90$ & $\begin{array}{c}10 \\
\mathrm{mmHg}\end{array}$ \\
\hline $\begin{array}{c}\text { Senin, } \\
11 \\
\text { Maret } \\
2019 \\
\end{array}$ & - & - & $130 / 90$ & $130 / 80$ & $\begin{array}{c}10 \\
\mathrm{mmHg}\end{array}$ \\
\hline $\begin{array}{c}\text { Selasa, } \\
12 \\
\text { Maret } \\
2019 \\
\end{array}$ & - & - & $140 / 90$ & $130 / 80$ & $\begin{array}{c}10 \\
\mathrm{mmHg}\end{array}$ \\
\hline
\end{tabular}


Berdasarkan tabel 3. diketahui setelah dilakukan intervensi terapi rendam kaki selama 3 hari terjadi penurunan tekanan darah dari hari pertama sampai dengan hari ketiga. Pada hari pertama, tanggal 6 Maret 2019 tekanan darah Tn. A sebelum dilakukan terapi yaitu $160 / 100 \mathrm{mmHg}$, setelah dilakukan terapi menjadi 140/90 $\mathrm{mmHg}$.

Pada hari kedua tanggal 7 Maret 2019 dilakukan pengukuran tekanan darah sebelum terapi yaitu 130/90 $\mathrm{mmHg}$, setelah dilakukan terapi tekanan darah menjadi 130/80 mmHg. Pada hari ketiga tanggal 8 Maret 2019 penulis melakukan pengukuran tekanan darah sebelum dilakukan terapi yaitu 130/80 mmHg, kemudian setelahnya dilakukan pengukuran tekanan darah menjadi 120/80 mmHg.

Sedangkan, pada hari pertama tanggal 8 Maret 2019 tekanan darah Ny. $\mathrm{M}$ sebelum dilakukan terapi yaitu 150/100 mmHg dan setelah dilakukan terapi menjadi 130/90 mmHg. Pada hari kedua, penulis baru dapat melakukannya pada tanggal 11 Maret 2019, penulis melakukan pengukuran tekanan darah sebelum terapi yaitu $130 / 90 \mathrm{mmHg}$, setelah dilakukan terapi menjadi 130/80 mmHg. Pada hari ketiga tanggal 12 Maret 2019 tekanan darah sebelum dilakukan terapi yaitu 140/90 $\mathrm{mmHg}$, lalu dilakukan observasi terapi mandiri dan setelah terapi tekanan darah menjadi 130/80 mmHg.

\section{Kesimpulan}

Berdasarkan hasil studi kasus mengenai penerapan terapi rendam kaki menggunakan air hangat dalam menurunkan tekanan darah pada klien dengan hipertensi dapat disimpulkan bahwa pelaksanaan terapi rendam kaki diperoleh adanya penurunan tekanan darah sesudah dilakukan terapi 1 kali selama tiga hari. Terapi redam kaki air hangat ini mampu menurunkan frekuensi nadi dan menurunkan tekanan darah dengan cara melebarkan pembuluh darah. Dimana hasil pengukuran tekanan darah pada hari ketiga pada subjek I sebelum terapi adalah 160/100 $\mathrm{mmHg}$, sesudah terapi rendam kaki 120/80 $\mathrm{mmHg}$.

Sedangkan pada subjek II sebelum terapi tekanan darah 150/100 $\mathrm{mmHg}$, dan sesudah terapi rendam kaki 130/80 $\mathrm{mmHg}$, dengan selisih rata-rata penurunan tekanan darah sebelum dan sesudah di berikan terapi yaitu 10 $\mathrm{mmHg}$, serta terapi ini cukup efektif dilakukan untuk penurunan tekanan darah.

\section{Saran}

Dari hasil studi kasus ini diharapkan kepada subjek yang menderita hipertensi untuk melakukan terapi rendam kaki secara rutin dan kontrol ke fasilitas kesehatan secara teratur untuk mendapatkan tindak lanjut penatalaksanaan dari penyakit hipertensi hipertensi. Begitu juga dengan keluarga diharapkan dapat memberikan dukungan pada klien hipertensi untuk dapat melakukan terapi rendam kaki dan mengingatkan kontrol ke fasilitas kesehatan, selain itu penulis juga mengharapkan tenaga kesehatan dan kader dapat bekerjasama dalam melaksanakan terapi ini sebagai perawatan yang efektif dan dapat keluarga terapkan di rumah.

\section{Ucapan Terima Kasih}

Ucapan terima kasih kepada Kepala Puskesmas Kecamatan Pancoran, Kepala RT dan RW Kelurahan Pancoran, seluruh Kader Kesehatan yang telah membantu proses pengambilan data, serta kepada keluarga yang telah bersedia menjadi responden dalam pelaksanaan studi kasus ini.

\section{Daftar Pustaka}

Agoes, Azwar. (2011). Penyakit di Usia Tua. Jakarta: EGC. 
Ali, Zaidin. (2010). Pengantar Keperawatan Keluarga. Jakarta: EGC.

Brunner. (2013). Keperawatan Medikal Bedah. Jakarta: EGC.

Damayanti, Imelda. (2014). Keluarga Sejahtera. Musi Banyu Asin: Akademi Keperawatan Pemerintah Kabupaten Musi Banyu Asin.

Depkes. (2017). Masalah Hipertensi Di Indonesia. Diunduh dari http://www.depkes.go.id/article/pri nt/1909/masalah-hipertensi-diindonesia.html

Ferayanti. (2017). Efektivitas Terapi Rendam Kaki Air Hangat Dan Relaksasi Nafas Dalam Terhadap Tekanan Darah. Yogjakarta: Universitas Respati Yogjakarta.

Friedman. (2010). Buku Ajar Keperawatan Keluarga : Riset, Teori, Praktek. Edisi ke-5. Jakarta: EGC.

Harmoko. (2012). Asuhan Keperawatan Keluarga. Yogjakarta: Pustaka Pelajar.

Istiqomah. (2017). Pengaruh Hidroterapi Rendam Kaki Air Hangat Terhadap Tingkat Tekanan Darah Pada Lansia Penderita Hipertensi Di Dusun Depok Ambarketawang Gamping Sleman Yogjakarta. Yogjakarta: Universitas Aisyiyah.

Lalage, Zerlina. (2015). Hidup Sehat Dengan Terapi Air. Yogjakarta: Abata Perss.

LeMone, Priscilla. (2017). Buku Ajar Keperawatan Medikal Bedah. Jakarta: EGC.

Lobo, dan Sakau. (2015). Asuhan Keperawatan Keluarga. Kupang: STIKES Husada Mandiri.

Mahmudah, Solehatul. (2015). Hubungan Gaya Hidup Dan Pola Makan Dengan Kejadian Hipertensi Pada Lansia Di Kelurahan Sawangan Baru. Jurnal Biomedika Volume 7 Nomor 2. Diunduh dari https://jounals.ums.ad.id.
Nadirawati. (2018). Buku Ajar Asuhan Keperawatan Keluarga. Bandung: PT Refika Aditaina.

Notoatmodjo. (2012). Promosi Kesehatan dan Perilaku Kesehatan. Jakarta : Rineka Cipta.

Nursalam. (2015). Metodologi Penelitian Ilmu Keperawatan: Pendekatan Praktis. Jakarta: Salemba Medika.

Potter, P.A dan Perry, A.G. (2005). Fundamental of nursing: concept, process, and practice.Ed 4 Vol 2.

Restuningtyas. (2019). Teori Rendam Kaki Air Hangat. Jember: Universitas Jember.

RISKESDAS. (2018). Laporan Nasional RISKESDAS 2018. Jakarta: Kementrian Kesehatan RI.

Sumijatun. (2010). Konsep Dasar Menuju Keperawatan Profesional. Jakarta: TIM.

Tilong, A.D. (2015). Dasyatnya Air Putih. Yogjakarta: Flash Book.

Triyanto, E. (2014). Pelayanan Keperawatan Bagi Penderita Hipertensi Secara Terpadu. Yogjakarta: Graha Ilmu.

Udjianti, Wajan Juni. (2011). Keperawatan Kardiovaskular. Jakarta: Salemba Medika.

Yessi, H.\& Astri, A. (2017). Terapi Rendam Kaki Menggunakan Air Hangat Efektif Menurunkan Tekanan Darah Pada Usia Lanjut. Jurnal Kesehatan Komunitas;3(4):129-132. Diunduh dari http://jurnal.htp.ac.id. 